\title{
Frontline
}

\section{Journalism as a research discipline}

\section{ABSSTRACII}

This article reviews recent debate about the performance and impact of the Excellence for Research in Australia (ERA) evaluations in 2010 and 2012 on the field of journalism research, in particular discussion of the relationship between research in journalism and that in the fields of communication, media and cultural studies. In response to that discussion and the initiation of the Frontline section in this journal (Bacon, 2012; Abplanalp, 2012; Gooch, 2012; Fitzgerald, 2013) it strongly argues that journalism is a distinct field of academic research practice. It identifies and briefly canvasses a range of methodological issues arising from Stuart Adam's (1994) characterisation of journalism research as addressing the real, the present and the public (p. 13), and issues arising from shifting technologies and editorial/peer review processes. It indicates a range of methodological literature in cognate disciplines that can be used to ground journalism as a distinct research practice among the humanities and arts disciplines.

Keywords: communication, cultural studies, investigative journalism, journalism education, journalism research, media studies, methodology, professional writing, reflexivity, research practice

\section{CHRIS NASH}

Monash University

7 HE COMPETITIVE evaluation of research performance in academic disciplines among universities has become a major part of institutional and individual life for scholars in Britain, Australia and New Zealand, and the trend is likely to spread inexorably to other national systems. It can be both an opportunity and a challenge, and its benefits and difficulties are hotly contested among the disciplines and institutions. Australian journalism academics are currently gearing up for the 2015 round of the Excellence for Research in Australia (ERA) reporting and evaluation process, 
following the mixed results of the 2010 and 2012 rounds (Richards, 2013; Bacon, 2013). Following each of the rounds, Australian Journalism Review $(A J R)$ published a set of analyses and interpretations of the results (Volumes 33(1) and 35(1) respectively). Continuing issues within institutions are the balance between traditional and non-traditional research outputs to be submitted, and selection of the appropriate Field of Research (FoR) code for submission.

In their analyses of the 2010 outcomes, Turner (2011, p. 5), Meadows (2011, p. 13), Richards (2011, p. 17) and Dunn (2011, p. 22) raised the issue of overlap and the dilemmas confronted by both individual researchers and institutions over whether to submit their work under the Code FoR1903 Journalism and Professional Writing or either FoR2001 Communication and Media Studies or FoR2002 Cultural Studies. Pearson (2011, p. 26), Knight (2011, p. 32), Nolan \& Lester (2011, p. 43) discussed the institutional politics and ramifications of this dilemma for journalism research practitioners, while Flew (2011, p. 35) went a step further to suggest that Journalism might better vacate the FoR19 code to join Communication, Media and Cultural Studies in FoR20.

In discussing the 2012 results, Phillips suggested a strategic alliance with the FoR20 fields of Communications and Cultural Studies (Phillips, 2013, p. 7ff), which Richards (2013) also endorsed. McNair (2013) took Flew's argument a step further again to echo Hartley (2008) and suggests that '[j] ournalism is too important to be left to the journalists' (p. 16). For McNair, journalism is clearly a 'practice' whose 'theory' is provided by communication, media and cultural studies, and he bemoans:

longstanding disciplinary tensions between 'practitioners' and 'theorists', who have tended to form hostile tribes rather than seeing themselves as allies in a broader academic enterprise of huge importance (which I would define as the production and dissemination of knowledge about journalism and its place in society). (McNair, 2013, p. 16)

In McNair's perspective, journalism is a research object in his discipline (communication/media studies) as a communication and social phenomenon; that is a very different beast from the research object of journalism, which is some nominated phenomenon of the contemporary world. Journalism research in reflexive mode may include journalism as a constituent aspect of 
the phenomenon being researched and reported on, but it is certainly not confined to this - indeed, far from it. For McNair, journalism is clearly not the subject or agent of research on its own disciplinary behalf. This perspective denies journalism the status of an academic research discipline already given it by the ARC. As a journalism academic, I welcome the focus of other disciplines on journalism as an object of their regard, be it history, sociology, political economy, geography, literary studies, cultural studies, communication studies or indeed health sciences or environmental sciences. Personally, the work in British cultural studies of Stuart Hall, a professor of sociology, was central to my own intellectual development as a journalism academic. Such research is a rich resource for a reflexive examination of any discipline as a social, textual or other practice. However, welcome as that regard and examination may be, it is not the same thing as journalism addressing its own disciplinary characteristics as a research practice. This is precisely the point James Carey (1996) was making in his famous address on 'Where Journalism education went wrong':

Axiom one: Journalism and journalism education is not a synonym or umbrella term for advertising, communications, media studies, public relations, or broadcasting. Journalism is a distinct social practice that comes into existence at a given moment in historical time and therefore must not be confused with these other related but distinct practices. Journalism must not be confused with them either in education or in the newsroom. Journalism education must take journalism itself as its distinct object of attention. (Carey, 1996)

At issue here is the fundamental question about the status and nature of journalism as a discrete research practice within the academy. Turner (2011) chaired the Humanities and Creative Arts Research Evaluation Committee for the 2009 ERA trial and noted

the claim that certain kinds of professional publications-feature articles, say, or a television documentary - demand recognition as research because of the scale and significance of the research effort that goes in their production. The ERA accepts that proposition. (Turner, 2011, p. 5)

Contra the position advanced by McNair and others, the ARC has recognised journalism as a research practice quite distinct from Communication, 
Media and Cultural Studies (they don't share even a two-digit FoR code), and operationalised that recognition through the ERA process. While in recognition of interdisciplinarity some journalism researchers might seek partially to code their research outside FoR1903, for example in sociology, history, geography, political science, media studies, cultural studies or the like, it would be a very strange thing indeed for a recognised discipline to abnegate its status in favour of some other discipline.

Put another way, the door against which many journalism academic researchers are pushing for recognition of their work is already open, and therefore the question is not whether journalism can be research, but what sort of journalism practice constitutes academic research, with the implicit corollary of its relationship to other disciplinary fields of research practice. Turner (2011) persuasively charges that some journalism academics are squandering this opportunity (p. 6), and I agree heartily with the gauntlet thrown down by British historian of journalism Martin Conboy (2011).

With regard to the product of journalism itself, it really is time for journalists - former, current, and those in transition within the academy - to take this bull by the horns and do what other subject areas have done and write an acceptable definition of journalism as research. (Conboy, 2011, p. 46)

This is by no means a forbidding challenge for journalism. Any such definition is of course not a simple set of dictionary phrases, but a distinctive engagement at an appropriate level with the ontological and epistemological issues raised by academic research as such, in Australia's case as defined by the Australian Research Council (2008):

Research is defined as the creation of new knowledge and/or the use of existing knowledge in a new and creative way so as to generate new concepts, methodologies and understandings. This could include synthesis and analysis of previous research to the extent that it leads to new and creative outcomes. (Australian Research Council, 2008, p. 1)

What follows is a brief outline of my approach to this challenge, currently the subject of a book-length exploration. I should say that my decision to publish this contribution in Pacific Journalism Review is by no means disrespectful to $A J R$ for its commendable engagement with this issue, but

126 PACIFIC JOURNALISM REVIEW 19 (2) 2013 
rather in response to the further step PJR has taken by initiating the Frontline section in its pages, thereby taking up Conboy's gauntlet. Frontline editor Wendy Bacon has outlined the history leading to the initiative (Bacon, 1997; 2012) and to date Abplanalp (2012), Gooch (2012) and Fitzgerald (2013) have accepted the challenge with investigative journalism examples as research. Earlier, AJR had published Bacon's (2006) and Lamble's (2004) calls in similar vein. Together, the two journals have encouraged leadership for Australasian scholars in addressing an important international challenge.

HE DISTINGUISHED historian Michel-Rolph Trouillot (1995) in
discussing the history and historiography of slavery in the Americas observed that most published history was not produced as an academic endeavour (p. 18ff), and one could most certainly say the same thing about journalism. Indeed, journalism historically is linked as a corollary to universal freedom of expression in a democracy. However, its emergence as a craft and subsequently as a profession with a code of ethics (Lloyd, 1985; Ward, 2009) led to the identification of certain specialised (and contested) rights and responsibilities. Internationally, most nation states define it as a practice by adherence to professional codes of ethics relating to truth, and regulate its role and practice through legal instruments such as Bills of Rights, statutes and the common law, and in civil jurisprudence. In Australia there are some 300 pieces of legislation across state and federal jurisdictions that regulate journalism, notably in defamation, evidence, privacy and anti-terrorism legislation.

The accession to university status for journalism education has seen a further development and challenge to engage constructively with requirements for research as academic practice, which as noted above is not a matter of meeting dictionary definitions. What gives any research practice status as an academic discipline is its capacity to engage a distinctive set of rigorous scholarly criteria with its own practice in order to assess its quality, in Trouillot's instance, the accounts of Afro-American slavery and the Haitian revolution in both scholarly and popular histories.

Journalism is a research practice in so far as it originates truth claims of significance to publics about the state of the world in some particularity. It is also a craft, a profession, an aesthetic practice, a communication practice and so on, and is mostly produced and received in an industrialised and commer- 
cialised context. It is not alone in combining those attributes. The law, health sciences, education and history, not to mention the visual arts, architecture and music, readily spring to mind as comparable. In their multiple dimensions each profession/discipline can be of interest to other disciplines, for example, a history of legal practice, a sociology of medical practice, a geography of architectural practice, but fundamentally it must also be a discipline unto itself. Most practice in the professions is relatively mundane and is not intended to and will not create new knowledge for scholarship; nor will it in journalism, but that is not the point. The point is to establish the basis and criteria for enquiry in those disciplines such that it will constitute scholarly research practice, to be assessed and validated as such by peers.

Any such criteria for disciplinary status do not constitute a simple checklist, but manifest as a capacity to engage fruitfully and distinctively with meta-theoretical questions of ontology and epistemology. Inevitably that will lead to an interrogation of the status of disciplinarity in itself, and indeed it may be said that the capacity to make a distinctive contribution to such an interrogation is the defining characteristic of a discipline.

Journalism researches and reports on the contemporary state of affairs in any given situation.

If journalism is marked by its public voice, it is marked equally by its relation to the here and now. Michael Oakeshott, a British philosopher, once defined 'the world of history [as] the real world as a whole comprehended under the category of the past'. The world of journalism, by contrast, may be the real world as a whole comprehended under the category of the present ....[J]ournalism is avowedly about the present, not the past. (Adam, 1994, p. 13 [my emphasis])

Stuart Adam's much-quoted characterisation of journalism identifies three core concepts - the public, the present and the real - which in combination underpin the practice and therefore generate criteria for quality assessment. They themselves are the object of fierce interrogation and debate, and while not every piece of journalism will explicitly engage with that interrogation or debate, in order to qualify as research practice any piece of journalism should be able to locate itself through an exegesis with respect to a defensible position in such discussion.

The formulation of a research question in journalism (the answer to which

128 PACIFIC JOURNALISM REVIEW 19 (2) 2013 
is the answer to 'What's the story?') can adopt a range of modes: generative, inquisitional, forensic, performative, and so on. This necessarily involves recognising and explaining the position and purpose of the researcher or subject with respect to the research object, and likewise the position and perspective on the topic of the intended audience/readership. Journalism is always produced within and for a social context, and so shares with anthropology the opportunities and challenges of participant observation as a research practice (eg, Altman and Hinksman, 2010; Sutton, 2011). In any selected mode, the journalist researcher should be able to defend the adequacy of the research question and modality with respect to the truth claims being made.

Regarding 'the real', journalism characteristically claims to be evidencebased and so tends to a materialist paradigm; although 'the linguistic turn' in the humanities has been influential in journalism as elsewhere in recent decades, most practice taking a textualist or idealist approach would probably tend to submit itself as creative practice under other FoR codes than 1903. Empirically, journalism typically deploys established qualitative methodologies including direct observation and audio-visual recording, witness testimony, archival research, document/artefact discovery and analysis, interviewing and the like. Increasingly, quantitative data retrieval, compilation and analysis are also being deployed by journalists. Journalism is profoundly engaged with the politics of truth and knowledge. In any given academic instance the journalist researcher will need to be able to defend the adequacy of the empirical methodology to the truth claims being made. Historically within the profession, this has been termed 'the journalism of verification' which characterises 'objectivity' not as a goal but a method (Kovach and Rosenstiel, 2007, p. 78ff). This is not to argue for a crude positivism in journalistic research: the relationship between evidence and meaning is no more or less fraught in journalism than in any other discipline.

Temporality (and necessarily spatiality) are defining constituents of journalism (Tuchman, 1978), which makes history and geography cognate disciplines. Contemporaneity in journalism can apply to the phenomena being observed, and/or the spatio-temporal context of the journalist observer, and/or of the receiving public. Notably, eminent US journalist I.F. Stone in 1988 published the best-selling book The Trial of Socrates, a highly regarded work of historical journalism dealing with events two and a half millennia past. Arguably it is journalism in so far as it is mobilising evidence about a 
(albeit historical) situation to make a case of contemporary relevance about intellectual accountabilities to democratic publics. If it were an account of an historical situation simply on its own merits it would arguably be history. As a deeply researched and rigorously argued case, it is certainly not 'popular history'.

Conversely, journalism in 'live' formats such as broadcasting can require instantaneous interpretation and response, eg in live interviews. Concepts such as 'news sense' and intuition need to be addressed, which requires theorisation of practice (e. g. Bourdieu, Lefebvre, Schon) as well as spatio-temporality (e. g. Harvey, Lefebvre, Gell). Comparable issues arise in other disciplinary practices performed in real time and space, e. g. courtroom interrogation in legal practice, diagnosis and surgery in medical practice, classroom and online engagement in educational practice.

Journalism's rights and responsibilities in law and political philosophy derive from the concept of 'the public right to know' in democratic theory. The public and its putative rights are multi-dimensional concepts much researched, queried and discussed in various literatures. In other disciplines a direct address to the public may be desirable but ancillary to the intended audience of fellow scholars; in journalism it is a sine qua non. Necessarily it involves inquiry, pre-conceptions and understandings by journalists of who their publics might be, how they have been constructed and how they can be addressed and responded to. For the purposes of journalism as scholarly research practice, journalists must address and balance the interests and capacities of dual audiences: experts in the field being reported on, and the intended public.

If one follows Adam's (1994) comparison with history above so that journalism is concerned with 'the real world as a whole comprehended under the category of the present' (p. 13) then it is necessarily an interdisciplinary activity, as indeed most disciplines are. To be able to interrogate and report on the state of affairs in a field, e. g. environmental degradation, military conflict, economic activity, parliamentary politics, sport, etc, journalism has to be familiar with the structure and processes of that field, and the criteria and procedures for verification of truth claims made in that field or discipline. To operate at the higher level of academic research practice, journalism has to be able to calibrate itself against the state of scholarship in the relevant field. That is not to say that journalism becomes a subset of the relevant discipline, nor a mere exercise in popular communication on behalf of elements in that discipline: 
journalism as such is always an independent interrogation and evaluation on behalf of the public and not on behalf of vested interests. Nonetheless, to be a valid and effective interrogation and evaluation, journalism has to be able to calibrate its truth claims against the standards of the field. Conversely, the character of any journalistic truth claim about a given situation may affect the individual and collective interests of participants in that field and its associated discipline. The need for independent critical engagement is mutual. The role of the exegesis in detailing the state of the field and appropriateness of the journalistic methodologies is crucial in these respects.

The technologies and forms of interrogation and communication in journalism are multifarious and rapidly changing, as are the industrial and commercial frameworks for production and reception, of which social media are only the most recent manifestation. Because of the constitutive element of 'the present' in journalism, it is always an iterative process updating the state of affairs in a field, and therefore the quality of a particular instance of journalism cannot be characterised by its length or volume. For example, a short news report in a breaking story may capture the essence of the contemporary state of affairs, just as a one-line formula in mathematics or physics may embody a paradigm shift in that discipline. The criterion of scale and comparability of contribution to a research effort is always a question of quality, in which the quantity of the resultant publication is only one of several contingent indicators. Nonetheless, unless the journalism is in long-form, e. g. a book, extended essay, documentary or detailed website, then journalism will often need to be presented in a portfolio of linked material in order to interpret and assess the fullness and quality of its contribution to knowledge. The role of the exegesis, brief or fulsome, is again crucial in this respect.

Likewise, the forms of editorial control and peer review in journalism are very fluid at the present time, as public and private sector business models are challenged, change or collapse. It is an urgent priority for journalists seeking recognition of their research practices as scholarly in the academic environment to establish mechanisms for peer review that bypass the vicissitudes of corporate oligopolies and the potential idiosyncrasies of self-publication on the web. This is an exciting challenge in which some decisive steps have been taken, e. g. the establishment in Australia of journalism as a unique field of research (FoR code 1903) and its peer assessment against world standards in successive ERA processes, and the association of non-for-profit centres of 
journalistic excellence with universities in the United States. The challenge for journalism parallels the challenge for history that Trouillot identified with respect to slavery in the Americas. Further, it goes to the heart of the exploration of what distinctive contribution journalism makes as a discipline sitting at the table with other disciplines in the production of knowledge.

Nolan \& Lester (2011) make the well-taken point that the 'placement of journalism studies as a named field under [FoR]19 and 1903 forces us to engage more concretely with ways of combing reflective analysis and developing forms of practice as research, most immediately perhaps at RHD [research higher degree] level'. (p. 42). For both journalism educators and for working journalists wishing to develop their own scholarly research practice as journalists, doctoral programmes and graduate seminars are an excellent venue to explore some of the issues outlined above. My own university welcomed its first intake into the new PhD (Journalism) ${ }^{1}$ programme in 2013, combining mature journalists with decades of leadership in the profession with younger students at the early to mid-career stages. The compulsory coursework unit on Advanced Research Methodologies in Journalism ${ }^{2}$ explores the particularity and generality of methodological issues in journalism with reference to philosophy, sociology, history, geography, anthropology, literary and communication studies, aesthetics and politics. In 2013, it was an enormously stimulating and successful experience for teacher and students, and underlined just how interesting and enjoyable the position of a journalism research academic can be in the contemporary university.

In conclusion, Turner (2011) and Conboy (2011) have starkly characterised the challenge and opportunity that the ERA process offers journalism academics in Australia, which puts us on the international frontline in the development and recognition of our research practices as serious intellectual and disciplinary endeavours in their own right. Debate over disciplinary foundations and boundaries is the very stuff of scholarly endeavour, and can often manifest as contests over turf within institutions. Those contests are important and need to be engaged with, but they can also be a distraction from the hard work of producing the journalism that generates new knowledge, methodologies and understandings, and developing the rigorous framework for peer evaluation of its quality. No one else is going to do it for us. 


\section{Notes}

1. www.monash.edu.au/pubs/handbooks/courses/4103.html Retrieved on August 29, 2013.

2. www.monash.edu.au/pubs/2013handbooks/units/APR6035.html Retrieved on August 29, 2013.

\section{References}

Abplanalp, K. (2012). 'Blood money': A NZ investigative journalism case study. Pacific Journalism Review, 18(1), 128-147.

Adam, G. S. (1994). Notes towards a definition of journalism: Understanding an old craft as an art form. Poynter Papers No. 2, The Poynter Institute for Media Studies

Altman, J., \& Hinksman, M. (2010). Culture crisis: Anthropology and politics in Aboriginal Australia. Sydney: UNSW Press.

Australian Research Council (2008). ERA indicator descriptors. Retrieved August 29, 2013, from www.arc.gov.au/pdf/ERA_Indicator_Descriptors.pdf

Bacon, W. (1999). What is a journalist in a university? Media International Australia, 92, 79-90.

Bacon, W. (2006). Journalism as research. Australian Journalism Review, 28(2),147157.

Bacon, W. (2012). An innovative direction in academic journalism. Pacific Journalism Review, 18(2), 153-165.

Bacon, W. (2013). ERA 2012: Loking back, looking forward. Australian Journalism Review, 35(1), 23-26.

Bourdieu, P. (1977). Outline of a theory of practice. Cambridge: Cambridge University Press.

Bourdieu, P., \& Wacquant, L. (1992). An invitation to reflexive sociology. Cambridge: Polity Press.

Carey, J. (1996). Where journalism education went wrong. Paper presented to the 1996 Siegenthaler Conference on Journalism Education, the First Amendment Imperative, and the Changing Media Marketplace, at Middle Tennessee State University.

Conboy, M. (2011). Glimpses of potential amidst the devilish detail: Assessing research in journalism studies in the UK. Australian Journalism Review, 33(1), 45-47.

Dunn, A. (2011). Understanding ERA: Why it matters. Australian Journalism Review, 33(1), 21-23.

Elden, S., Lebas E., \& Kofman, E. (2003). Henri Lefebvre: Key writings. New York: Continuum.

Fitzgerald, B. (2013). Climate change reporting in an Australian context: Recognition, adaptation and solutions. Pacific Journalism Review, 19(1), 203-219.

Flew, T. (2011) Is journalism best located in the creative arts or as a communication discipline? Australian Journalism Review, 33(1), 35-39.

Gell, A. (1992). The anthropology of time. New York: BERG.

PACIFIC JOURNALISM REVIEW 19 (2) 2013133 
Gooch, N. (2012). Background to 'Sulphate Sunrise'-investigating New Caledonia. Pacific Journalism Review, 18(1), 148-170.

Hartley, J. (2008). Journalism as a human right: The cultural approach to journalism. In Loffelholz, M. and Weaver, D. (2008), Global journalism research: Theories, methods, findings, future. Oxford: Blackwell.

Harvey, D. (2006). Spaces of global capitalism: Towards a theory of uneven development. London: Verso. c.4 'Space as a keyword'.

Knight, A. (2011). A new ERA for journalism educators. Australian Journalism Review, 33(1), 29-34.

Kovach, B., \& Rosenstiel, T. (2007). The elements of journalism: What newspeople should know and the public should expect. New York: Three Rivers Press.

Lamble, S. (2004). Documenting the methodology of journalism. Australian Journalism Review, 26(1), 85-106.

Lefebvre, H. (1991). The social production of space. Oxford: Blackwell.

Lefebvre, H. (2002). Critique of everyday life, Volume 2: Foundations for a sociology of the everyday. London: Verso.

Lloyd, C. (1985). Profession, journalist: A history of the Australian Journalists' Association. Sydney: Hale and Ironmonger.

McNair, B. (2013). ERA 2012: Worrying picture of the state of the field. Australian Journalism Review, 35(1), 15-18.

Meadows, M. (2011). The meaning of life: Journalism research and ERA 2010. Australian Journalism Review, 33(1), 9-15.

Nolan, D., \& Lester, L. (2011). Expanding journalism studies in a competitive environment. Australian Journalism Review, 33(1), 41-44.

Pearson, M. (2011). A poor fit for journalism research. Australian Journalism Review, $33(1), 25-27$.

Phillips, G. (2013). ERA 2012: Lose a battle, win the war-the future for journalism research. Australian Journalism Review, 35(1), 7-10.

Richards, I. (2011). Notes from the inside. Australian Journalism Review, 33(1), 17-19.

Richards, I. (2013). ERA 2012: Prelude to the aftermath? Australian Journalism Review, 35(1), 11-13.

Schön, D. (1983). The reflective practitioner: How professionals think in action. New York: Basic Books.

Stone, I.F. (1988). The trial of Socrates. Boston: Little, Brown and Company.

Sutton, P. (2011). The politics of suffering: Indigenous Australia and the end of the liberal consensus. Melbourne: Melbourne University Press.

Trouillot, M.R. (1995). Silencing the past: Power and the production of history. Boston: Beacon Press.

Tuchman, G. (1978). Making news: A study in the construction of reality. New York: Free Press.

Turner, G. (2011). The ERA and journalism research. Australian Journalism Review, $33(1), 5-7$.

Ward, S. (2009). Journalism ethics. In Wahl-Jorgensen, K. and Hanitzsch, T. (Eds.), The handbook of journalism studies. London: Routledge.

134 PACIFIC JOURNALISM REVIEW 19 (2) 2013 
Dr Chris Nash is foundation professor of journalism and head of the doctoral programme at Monash University in Melbourne, Australia, and is on the editorial board of Pacific Journalism Review.

chris.nash@monash.edu

\section{Journalism that won't sit still}

Papers are invited for the Journalism Education Association of New Zealand annual conference, to be held at AUT University, November 28-29, 2013.

Conference theme: The Mobile Age or \#journalism that won't sit still.

The ongoing disruption of 'traditional' journalism practice by digital technologies is encapsulated nowhere more succinctly than in the touch-screen mobile device still quaintly called a 'phone'. Growth in mobile consumption is strong as both consumers and journalists adjust to an age where no one needs to sit down for the news. Meanwhile, within the increasingly wireless network, participatory media continue to blur the lines around journalism. How should journalism educators respond?

Papers requiring blind peer review must be with conference convenors by September 30, 2013.

Please send 200-word abstracts and other inquiries to Greg Treadwell (gregory.treadwell@aut.ac.nz) or Dr Allison Oosterman (aoosterm@aut.ac.nz).

PACIFIC JOURNALISM REVIEW 19 (2) 2013135 